\title{
Larvicidal activity of hydroalcoholic extracts of Persea americana Mill. Seeds against
}

\section{Aedes aegypti}

\author{
Atividade larvicida dos extratos hidroalcóolicos das sementes de Persea americana Mill. frente
}

Aedes aegypti

Actividad larvicida de extractos hidroalcohólicos de semillas de Persea americana Mill. delantero

Aedes aegypti

Received: 07/12/2021 | Reviewed: 07/19/2021 | Accept: 08/01/2021 | Published: 08/06/2021

\author{
Ana Paula Muniz Serejo \\ ORCID: https://orcid.org/0000-0002-4376-4364 \\ Universidade Federal do Maranhão, Brazil \\ E-mail: apsmuniz1@gmail.com \\ Gustavo Oliveira Everton \\ ORCID: https://orcid.org/0000-0002-0457-914X \\ Universidade Federal do Maranhão, Brazil \\ E-mail: gustavooliveiraeverton@gmail.com \\ Helene do Carmo Castro Lacerda \\ ORCID: https://orcid.org/0000-0003-1511-8039 \\ Universidade Federal do Maranhão, Brazil \\ E-mail: helene-castro@ hotmail.com \\ Ana Patrícia Matos Pereira \\ ORCID: https://orcid.org/0000-0003-4478-4209 \\ Universidade Federal do Maranhão, Brazil \\ E-mail: ap.matos11@hotmail.com \\ João Pedro Mesquita Oliveira \\ ORCID: https://orcid.org/0000-0003-1833-9814 \\ Universidade Federal do Maranhão, Brazil \\ E-mail: joao-p01@live.com \\ Thaylanna Pinto de Lima \\ ORCID: https://orcid.org/0000-0003-1172-3004 \\ Universidade Federal do Maranhão, Brazil \\ E-mail: thaylanna.lima@discente.ufma.br \\ Maria Giulia Alves Carneiro Felizardo \\ ORCID: https://orcid.org/0000-0002-1921-9067 \\ Universidade Federal do Maranhão, Brazil \\ E-mail: giullia.73@hotmail.com \\ Denise Fernandes Coutinho \\ ORCID: https://orcid.org/0000-0002-5665-9280 \\ Universidade Federal do Maranhão, Brazil \\ E-mail: deniseufma2014@gmail.com
}

\begin{abstract}
This study aimed to evaluate the phytochemical composition of hydroalcoholic extracts from the seeds of Persea americana (avocado) and evaluate the larvicidal activity against Aedes aegypti. The extracts were obtained by maceration in a 70\% PA ethanol extractant solvent in 1:4/1:6/1:8 hydromodules (7 days), with subsequent concentration in a rotaevaporator. The larvicidal activity was performed by the method recommended by the WHO Lethal Concentration 50\% against Aedes aegypti larvae with statistics by the Probit method. Toxicity to non-target organisms was verified by the Artemia salina test. Activity was observed against Aedes aegypti larvae with LC 50 ranging from $181.72-401.96 \mathrm{mg} \mathrm{L}^{-1}$ with a $95 \%$ confidence interval. Finally, it states that the extract of $P$. americana has potential for larvicidal activity and does not present toxicity to target organisms, showing itself to be a sustainable alternative for the control and combat of Aedes aegypti larvae.
\end{abstract}

Keywords: Persea americana; Bioativos; Arboviroses; Vetores.

\section{Resumo}

Este estudo teve por objetivo avaliar a composição fitoquímica de extratos hidroalcóolicos das sementes de Persea americana (avocado) e avaliar a atividade larvicida frente Aedes aegypti. Os extratos foram obitdos por maceração em solvente extrator etanol 70\% P.A. em hidromódulos 1:4/1:6/1:8 (7 dias), com posterior concentração em rotaevaporador. A atividade larvicida foi realizada pelo método preconizado pela OMS de Concentração Letal $50 \%$ 
frente a larvas Aedes aegypti com estatística por método Probit. A toxicidade para organismos não-alvos foi verificada pelo teste de Artemia salina. Observou-se atividade frente a larvas Aedes aegypti com CL50 variando de 181,72$401,96 \mathrm{mg} \mathrm{L}^{-1}$ com intervalo de confiança de $95 \%$. Por fim, afirma que o extrato de $P$. americana apresenta potencial de atividade larvicida e não apresenta toxicidade a organismos alvos, mostrando-se uma alternativa sustentável ao controle e combate de larvas Aedes aegypti.

Palavras-chave: Persea americana; Bioactives; Arboviruses; Vectors.

\section{Resumen}

Este estudio tuvo como objetivo evaluar la composición fitoquímica de los extractos hidroalcohólicos de semillas de Persea americana (aguacate) y evaluar la actividad larvicida contra Aedes aegypti. Los extractos fueron obited por la maceración en etanol del extractor solvente el 70\% P.A. en hidromodules 1:4/1:6/1:8 (7 días), con la concentración subsecuente en rotaevaporator. La actividad larvicidal fue realizada por el método del WHO de Concentración Mortal el 50\% contra las larvas del Aedes aegypti con estadística del Probit. La toxicidad a los organismos de la no-blanco fue verificada por la prueba del Artemia salina. La actividad fue observada contra las larvas del Aedes aegypti con $\mathrm{CL}_{50}$ extendiéndose a partir del 181,72 al 401,96 $\mathrm{mg} \mathrm{L}^{-1}$ con un intervalo de confianza del 95\%. Por último, se afirma que el extracto de $P$. americana presenta potencial de actividad larvicida y no presenta toxicidad para los organismos diana, demostrando ser una alternativa sostenible al control y combate de las larvas de Aedes aegypti.

Palabras clave: Persea americana; Bioactivos; Arbovirus; Vectores.

\section{Introduction}

The Aedes mosquito is a vector that transmits arboviruses, has a wide geographic distribution and its expansion is influenced by several factors, including: its behavior, the large size of the urban population, the precariousness of the good proportion of households in relation to the water supply, inadequate disposal of waste, the increase in the number of nonbiodegradable containers and inadequate disposal of solid waste. Arboviruses are still considered infections with a great impact on public health, and their prevention and control is one of the main challenges (Moyses\&Bonatti, 2021).

The re-emergence of these diseases caused by arboviruses and transmitted by mosquitoes is observed, with emphasis on Dengue, Chikungunya Fever, Yellow Fever and Zika Fever in several countries in the Americas and in other tropical regions. The entry of these viruses in Brazil, a country already endemic for Dengue, represents a major challenge for public health, as they are all susceptible to infections and there are still no specific antivirals, nor vaccines for prevention free from side effects (Viana et al., 2018 ).

In the absence of dengue drugs and the variable safety and efficacy of the dengue vaccine, Dengvaxia (Thomas\&Yoon., 2019), vector control remains the mainstay of Dengue control programs (Chang et al., 2011). Several plants have been used by humanity on all continents to control different diseases and pests, in addition to representing an important source of biologically active natural products, many of which constitute a model for the synthesis of a large number of drugs (Simões et al. 2017).

Therefore, the search for new larvicides from natural resources has always been the criterion for finding alternatives for mosquito control. The advantages of natural insecticides are non-polluting to the environment and are safe for human health. Several natural products have been shown to have mosquito repellent, larvicides, pupicide and ovicidal activities (Shaalan et al., 2005; Nerio et al., 2009; Pavela, 2015; Kishore et al., 2011; Ghosh et al., 2012).

Within this, the search for new pesticides from natural resources has been the criterion for finding alternatives for the control of arbovirus vectors. The advantages of natural biolarvicides include the fact that they are environmentally friendly and safe for human health. Thus, natural products have shown potential in the action of controlling and combating larvicide, pupicide and ovicide (Shaalan et al., 2005; Ghosh et al., 2012; Nerio et al., 2010; Kishore et al., 2011; Pavela, 2015).

Several plants, despite being consumed as functional foods and/or nutraceuticals, are used for bioprospective research, which means the search for chemical products with biological or pharmacological properties that can be used to treat various diseases. 
Among these, stands out Persea americana Mill. (Lauraceae), being an evergreen tree found and cultivated in the tropical and subtropical region of the world. It's called the avocado fruit and it's edible. In traditional medicine, the plant is reported for a variety of diseases such as heart, skin problems, hypertension, diabetes, bronchitis and diarrhea (Yasir et al., 2010; Dabas et al., 2013). Therefore, considering the importance of finding natural biolarvicides, this study aimed to evaluate the larvicidal activity of hydroalcoholic extracts from P. americana seeds against Aedes aegypti.

\section{Methodology}

\subsection{Botanical material}

Fruits of Persea americana were collected from a site located in the Ipem Turu, in the municipality of São Luis, MA in November 2020 . These were dried at $40^{\circ} \mathrm{C}$ in an air-circulation oven and pulverized in a knife mill with moderately coarse powder particle size. . Exsiccates were made with flowering branches and sent to the Ático Seabra Herbarium, at the Center for Biological and Health Sciences at the Federal University of Maranhão, for confirmation of their botanical identification.

\subsection{Obtaining hydroalcoholic extracts}

To obtain the hydroalcoholic extracts, the maceration technique was used using an ethanol extracting solvent $70 \%$ PA in hydromodules of 1:4, 1:6 and 1:8 (m/v), in 70\% ethanol. The maceration will be carried out for 10 days, under agitation and filtration (Figure 1).

Figure 1. Filtration processing using the vacuum system to separate the extract solid from the extracting solvent after 10 days of maceration.

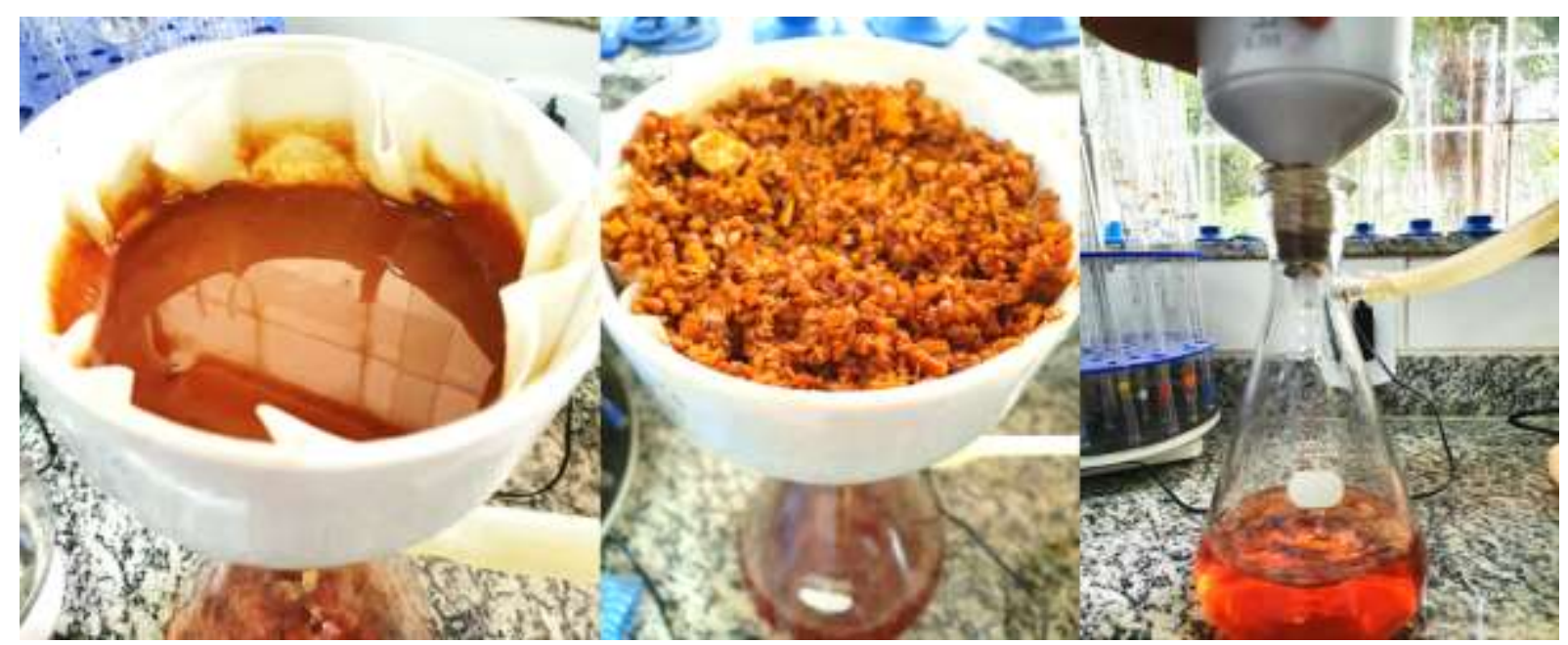

Source: Authors (2021).

The resulting extracts, observed in Figure 1, were concentrated in a rotaevaporator (Figure 2) and stored in a refrigerator at $4^{\circ} \mathrm{C}$ in amber colored flasks (Matos, 2009). 
Figure 2. Rotaevaporation of the extracting solvent to concentrate the hydroalcoholic extract.

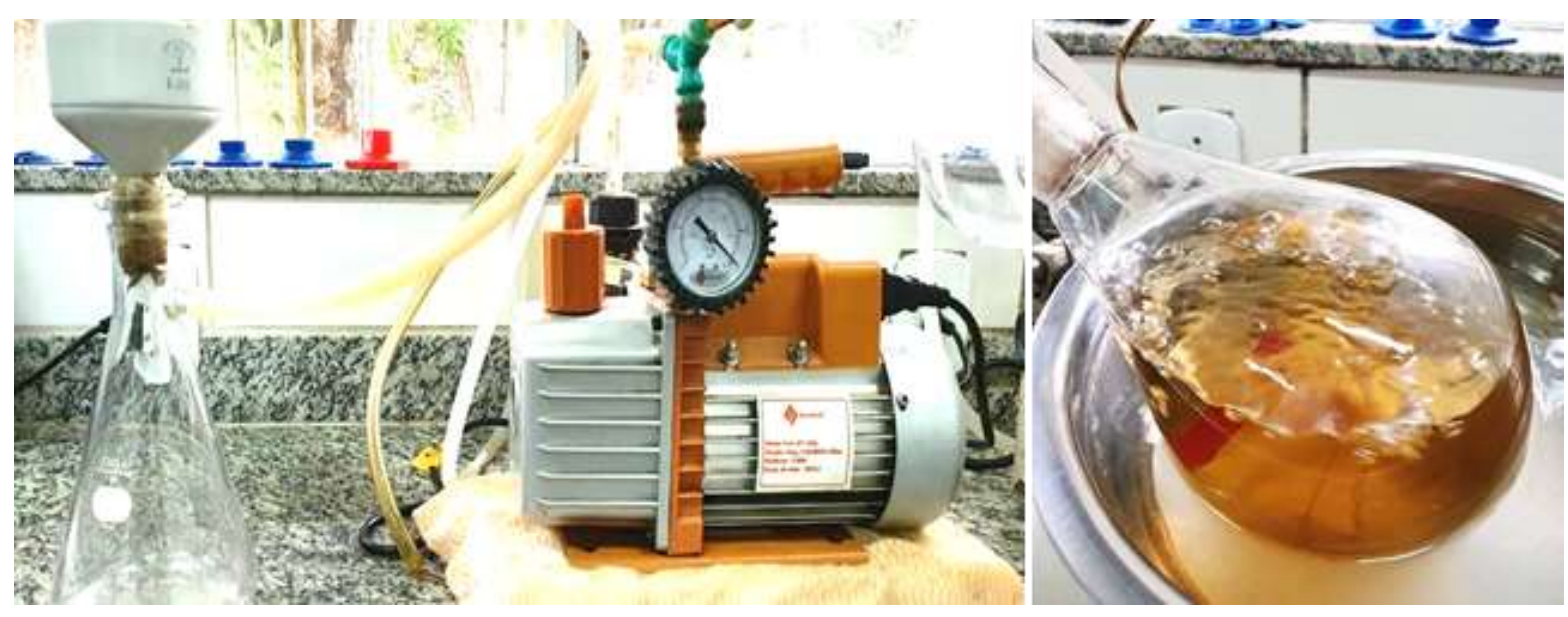

Source: Authors (2021).

The extracts yields were calculated by gravimetric technique and the physicochemical parameters: density and refractive index were determined according to the techniques recommended by the Brazilian Pharmacopoeia (2019).

\subsection{Phytochemical analysis}

The extracts were subjected to chemical tests based on the methodology presented by Matos (2009). The tests performed were: Salkowsk test (steroids), Mayer test (alkaloids), flavonoids, glycosides, saponins test, keller kiliani test (cardiac glycosides), ferric chloride test (phenols) and lead acetate test ( tannins). And the total phenolic content was quantified through the spectrophotometric method of Folin-Ciocalteau and the total flavonoid through the spectrophotometric method of complexation with aluminum (Lugasi et al., 1998; Oliveira et al., 2009).

\subsection{Collection of Aedes aegypti eggs}

The collection of Aedes aegypti eggs was carried out using traps called ovitraps, with the aid of Eucatex palettes. The Eucatex palettes were properly inspected, sanitized and dried before setting up the traps. The traps were installed at various points on the campus of the Universidade Federal do Maranhão, Recanto dos Vinhais (São Luís, MA) and Alemanha (São Luís, MA) under shelter from the sun and rain. The collected eggs were hatched in mineral water and fed until the stage where the experiments were carried out.

\subsection{Larvicide activity against Aedes aegypti}

The tests for larvicidal activity were carried out according to the adapted methodology proposed by Silva (2006). Initially, a $500 \mathrm{mg} \mathrm{L}^{-1}$ stock solution of each of the hydroalcoholic extracts was prepared and diluted in a $2 \%$ Tween 80 solution. From this solution, serial dilutions were prepared at concentrations 100-400 $\mathrm{mg} \mathrm{L}^{-1}$. At each concentration, 10 larvae were added at the rate of $2 \mathrm{ml}$ per larva.

All tests were performed in triplicate and as negative control a solution made up of $2 \%$ Tween 80 was used, and as positive control, a solution of temephos (O,O,O', $\mathrm{O}^{\prime}$-tetramethyl O,O'-thiodi- p-phenylene bis (phosphorothioate) at $100 \mathrm{ppm}$, equivalent to the concentration used by the National Health Foundation (FUNASA) for the larvicide control of the vector, in addition to Novaluron ( \pm -1-[3-chloro-4-(1-1-) 3-trifluro-2-trifluoromethoxyethoxy) phenyl-3-(2,6-diflurobenzoyl) urea at 0.02 $\mathrm{mg} \mathrm{L}{ }^{-1}$, dose adopted by the Ministry of Health, indicated by the WHO in the range of 0.01 to $0.05 \mathrm{mg} \mathrm{L}^{-1}$.

After 24 hours the count of live and dead was carried out, and larvae that did not react to touch after 24 hours of the 
beginning of the experiment were considered dead. To quantify the efficiency of the extracts, the Probit statistical test (Finney, 1952) was applied.

\subsection{Toxicity assessment against Artemia salina}

This test was performed according to the methodology described by Meyer et al. (1982). To assess the lethality of Artemia salina Leach, a stock saline solution of each hydroalcoholic extract was prepared at a concentration of $10,000 \mathrm{mg} \mathrm{L}^{-1}$ and $0.02 \mathrm{mg}$ of Tween 80 (active tension). Aliquots of this were transferred to test tubes and supplemented with saline solution previously prepared up to $5 \mathrm{~mL}$, obtaining in the end concentrations of $1000-10 \mathrm{mg} \mathrm{L}^{-1}$, respectively, where ten larvae in the nauplial stage were transferred to each of the tubes of rehearsal.

For the blank, $5 \mathrm{~mL}$ of saline solution was used, for the positive control $\mathrm{K} 2 \mathrm{Cr} 2 \mathrm{O} 7$ and for the negative control $5 \mathrm{~mL}$ of a $4 \mathrm{mg} \mathrm{L}^{-1}$ solution of Tween 80. After 24 hours of exposure, the count of live larvae was performed, considering dead those that did not move during the observation or with the slight shaking of the flask.

The criterion established by Dolabela (1997) was adopted to classify the toxicity of hydroalcoholic extracts, being considered highly toxic when $\mathrm{LC}_{50} \leq 80 \mathrm{mg} \mathrm{L}^{-1}$, moderately toxic for $80 \mathrm{mg} \mathrm{L}^{-1} \leq \mathrm{LC}_{50} \geq 250 \mathrm{mg} \mathrm{L}^{-1}$ and slightly toxic or nontoxic when $\mathrm{LC}_{50} \geq 250 \mathrm{mg} \mathrm{L}^{-1}$.

The statistical analysis of the data for the toxicity test was carried out according to the method of Reed\&Muench (1938). The intersection point between the curves is the 50\% Lethal Concentration $\left(\mathrm{LC}_{50}\right)$, since at this point the number of surviving animals is equal to the number of dead animals (Colegate; Molyneux, 2007).

\section{Results and Discussion}

\subsection{Phytochemical parameters and phytochemical screening}

The physicochemical parameters are important for determining aspects of biological applications and are presented in Table 1.

Table 1. Physicochemical parameters of the hydroalcoholic extract of Persea Americana.

$\begin{array}{ccc}\text { Parameter } & \text { Density }\left(\mathbf{g ~ m L}^{-\mathbf{1}}\right) & \text { Refractive Index }\left(\mathbf{n D} \mathbf{~ 2 5}^{\circ}\right) \\ \text { EHPA1:8 } & 0.9140 & 1.345 \\ \text { EHPA1:6 } & 1.0386 & 1.351 \\ \text { EHPA1:4 } & 0.9440 & 1.339\end{array}$

Source: Authors (2021).

In a study conducted by Ferrari (2015) evaluating the oil refraction index of $P$. americana seed, it verified a variation of 1.4620 to $1.4625 \mathrm{nD} 25^{\circ}$. In another analysis by Jorge (2014) of the pulp oil of this species, $1.4615 \mathrm{nD} 25^{\circ}$. Results close to the one found in this search can be found. There is a scarcity of data in the literature regarding the density of extracts from the studied vegetable.

The classes of secondary metabolites identified in the extracts obtained from Persea americana are shown in Table 2. 
Table 2. Classes of secondary metabolites identified in extracts obtained from the seeds of Persea americana.

\begin{tabular}{|c|c|c|c|c|c|c|c|c|}
\hline Hydroalcoholic extracts Persea americana & 1 & 2 & 3 & 4 & 5 & 6 & 7 & 8 \\
\hline EHPA1:8 & + & - & + & + & + & + & + & + \\
\hline EHPA1:6 & + & - & + & + & + & + & + & + \\
\hline EHPA1:4 & + & - & + & + & + & + & + & + \\
\hline
\end{tabular}

Note: 1-Steroids,2-Alkaloids,3-Flavonoids,4-Glycosides, 5-Cardiac Glycosides, 6-Saponins, 7-Phenols,8-Taninos. Source: Authors (2021).

Through the phytochemical study, the following metabolites were identified in the researched extracts: steroids, flavonoids, glycosides, cardiac glycosides, saponins, phenols and tannins, presented in Table 2. The diversity of active compounds present is highlighted, suggesting a high biological potential. Deuschle et al. (2018) evidenced the presence of phenolic compounds and flavonoids in hydroalcoholic extracts of P. americana leaves. Athayde et al. (2018) that evaluated the hydroalcoholic extracts of seeds of the studied species registered the presence of phenolic metabolites, tannins and flavonoids.

Table 3 shows the total phenolic content identified in the extracts of P. americana.

Table 3. Total phenolic content (mg EAT $\left.\mathrm{g}^{-1}\right)$ quantified for extracts obtained from Persea americana seeds.

\begin{tabular}{|c|c|c|c|}
\hline Extract & $\begin{array}{l}\text { Total phenolic content } \\
\qquad\left(\mathrm{mg} \mathrm{EAT} \mathbf{g}^{-1}\right)\end{array}$ & Equation & $\mathbf{R}^{2}$ \\
\hline EHPA1:8 & 163.90 & & \\
\hline EHPA1:6 & 126.34 & $y=0.0586+0.06$ & 0.9998 \\
\hline EHPA1:4 & 87.07 & & \\
\hline
\end{tabular}

Note: EHPA - Persea americana hydroalcoholic extract. Source: Authors (2021).

Similar results were described by Rotta et al. (2016) when quantifying the content of phenolics in dehydrated $P$. americana bark and resulted in a quantity of $108.48 \pm 1.62 \mathrm{mg} \mathrm{GAE} \mathrm{g}^{-1}$ ). In another study by Athayde et al. (2019) with hydroalcoholic extracts of $P$. americana seeds, the authors verified a total phenolic content quantified in $366.79 \pm 5.05 \mathrm{mg}$ $\mathrm{EAG} \mathrm{g}^{-1}$.

Table 4 shows the total flavonoid content identified in the extracts of P. americana.

Table 4. Total flavonoid content (mg EQ $\left.\mathrm{g}^{-1}\right)$ quantified for extracts obtained from Persea americana seeds.

\begin{tabular}{|c|c|c|c|}
\hline Extract & $\begin{array}{c}\text { Total flavonoid content } \\
\qquad\left(\mathrm{mg} \mathrm{EQ} \mathrm{g}^{-1}\right)\end{array}$ & Equation & $\mathbf{R}^{2}$ \\
\hline EHPA1:8 & 153.44 & & \\
\hline EHPA1:6 & 120.31 & $y=0.0033 x+0.006$ & 0.9845 \\
\hline EHPA 1:4 & 90.109 & & \\
\hline
\end{tabular}

Source: Authors (2021).

Similar results were also evidenced by Rotta et al. (2016) the flavonoid content of $136.034 \pm 1.88 \mathrm{mg}^{\mathrm{EQ}} \mathrm{g}^{-1} \mathrm{in}$ 
dehydrated bark of $P$. americana, there is a result well above that identified in our study. Athayde et al. (2019) when evaluating $P$. americana seed extracts recorded $28.09 \pm 0.64 \mathrm{mg}^{\mathrm{EQ} \mathrm{g}} \mathrm{g}^{-1}$.

Gobbo-Neto et al. (2007) claim that there are factors that influence the content of secondary metabolites, among them, one of the most relevant is the period of the year in which the vegetable was collected. Another important factor is the age and development of the plant, as well as the temperature of its habitat, the water supply of the soil in which the plant is grown, exposure to ultraviolet radiation, rainfall and altitude. Therefore, these causes can cause a variation of secondary metabolites in plants.

\subsection{Lethality against Artemia salina Leach.}

Table 5 presents the results regarding the lethality toxicity test against Artemia salina Leach.

Table 5. Mortality Artemia salina Leach against the action of the hydroalcoholic extract of Persea americana in 1:8, 1:6 and $1: 4$ hydromodule $(\mathrm{m} / \mathrm{v})$.

\section{Accumulated curve intersection log}

$\begin{array}{llcr}\text { EHPA 1:8 } & 2,95 & 891,30^{\mathrm{ab}} & \text { Non toxic }^{\mathrm{c}} \\ \text { EHPA 1:6 } & 2,93 & 851,10^{\mathrm{ab}} & \text { Non toxic }^{\mathrm{c}} \\ \text { EHPA 1:4 } & 2,92 & 831,80^{\mathrm{ab}} & \text { Non toxic }^{\mathrm{c}}\end{array}$

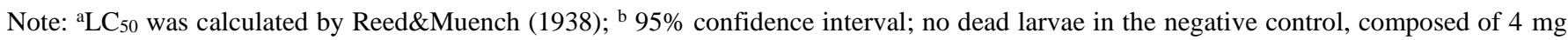
$\mathrm{L}^{-1}$ Tween 80; the positive control, $\mathrm{K}_{2} \mathrm{Cr}_{2} \mathrm{O}_{7}$, had $100 \%$ larval mortality; 'Dolabela (1997). Source: Authors (2021).

The relationship between the degree of toxicity and the mean lethal concentration $\left(\mathrm{LC}_{50}\right)$ presented for medicinal plant extracts on Artemia salina larvae was established by the criteria adopted by Dolabela (1997) for classification of the toxicity of natural products. As observed in Table 5, all extracts obtained presented $\mathrm{LC}_{50}$ above $250 \mathrm{mg} \mathrm{L}^{-1}$, thus being defined as nontoxic, and their application was encouraged.

The nontoxicity profile found in this study is confirmed by Valente (2020) who found a $\mathrm{LC}_{50}$ of $452.57 \mathrm{mg} \mathrm{L}^{-1}$ for the seed extract of P. americana against Artemia salina. However, toxicity profiles are reported by Amado et al. (2019) when evaluating the toxicity also against Artemia salina, but with the ethanolic extract of the bark of the Quintal variety of the Persea americana species, where the $\mathrm{LC}_{50}$ found was $204.95 \mathrm{mg} \mathrm{L}^{-1}$. Therefore, it is important to emphasize the use of seed extract in practical applications, aiming at its atoxicity potential, inferring its selectivity to target organisms.

\subsection{Lethality against Aedes aegypti}

Table 6 presents the results regarding mortality Aedes aegypti against the action of the hydroalcoholic extract of the seeds of $P$. americana. 
Table 6. Mortality Aedes aegypti against the action of the hydroalcoholic extract of Persea americana in 1:8, 1:6 and 1:4 hydromodule $(\mathrm{m} / \mathrm{v})$.

\begin{tabular}{|c|c|c|c|c|c|c|}
\hline & $\log C$ & $\%$ Mortality & $\begin{array}{c}\mathrm{LC}_{50}\left(\mathrm{mg} \mathrm{L}^{-1}\right) \\
95 \% \mathrm{CI}\end{array}$ & $\mathbf{X}^{2}$ & $\sigma$ & $\mathbf{R}^{2}$ \\
\hline \multirow{6}{*}{$\begin{array}{c}\text { EHPA } \\
1: 8\end{array}$} & 2.00 & 30.0 & \multirow{5}{*}{$(121.95-270.91)^{\mathrm{b}}$} & \multirow{5}{*}{0.626} & \multirow{5}{*}{0.465} & \multirow{5}{*}{0.978} \\
\hline & 2.30 & 50.0 & & & & \\
\hline & 2.48 & 70.0 & & & & \\
\hline & 2.60 & 100.0 & & & & \\
\hline & 2.70 & 100.0 & & & & \\
\hline & $\log C$ & \% Mortality & $\begin{array}{c}\mathrm{LC}_{50}\left(\mathrm{mg} \mathrm{L}^{-1}\right) \\
95 \% \mathrm{CI}\end{array}$ & $\mathbf{X}^{2}$ & $\sigma$ & $\mathbf{R}^{2}$ \\
\hline \multirow{6}{*}{$\begin{array}{c}\text { EHPA } \\
1: 6\end{array}$} & 2.00 & 10.0 & \multirow{5}{*}{$(273.85-589.85)^{\mathrm{b}}$} & \multirow{5}{*}{0.993} & \multirow{5}{*}{0.444} & \multirow{5}{*}{0.978} \\
\hline & 2.30 & 20.0 & & & & \\
\hline & 2.48 & 40.0 & & & & \\
\hline & 2.60 & 50.0 & & & & \\
\hline & 2.70 & 60.0 & & & & \\
\hline & $\log C$ & \% Mortality & $\begin{array}{c}\mathrm{LC}_{50}\left(\mathrm{mg} \mathrm{L}^{-1}\right) \\
95 \% \mathrm{CI}\end{array}$ & $\mathbf{X}^{2}$ & $\sigma$ & $\mathbf{R}^{2}$ \\
\hline \multirow{5}{*}{$\begin{array}{c}\text { EHPA } \\
1: 4\end{array}$} & 2.00 & 40.0 & \multirow{5}{*}{$\begin{array}{c}181.72^{\mathrm{a}} \\
(83.02-397.76)^{\mathrm{b}}\end{array}$} & \multirow{5}{*}{0.265} & \multirow{5}{*}{0.963} & \multirow{5}{*}{0.978} \\
\hline & 2.30 & 50.0 & & & & \\
\hline & 2.48 & 60.0 & & & & \\
\hline & 2.60 & 100.0 & & & & \\
\hline & 2.70 & 100.0 & & & & \\
\hline
\end{tabular}

Note: ${ }^{\mathrm{a}} \mathrm{LC} 50$ was calculated by Probit analysis (Finney, 1952); ${ }^{\mathrm{b}}$ 95\% confidence interval; no dead larvae in the negative control, composed of $2 \%$ DMSO solution; the positive control, $1 \mathrm{mg} \mathrm{L}^{-1}$ temephos, had 100\% larval mortality. Source: Authors (2021).

As shown in Table 6, it is observed that the lowest $\mathrm{LC}_{50}$ was observed for EHPA1:4, quantified at $181.72 \mathrm{mg} \mathrm{L}^{-1}$. However, an action similar to EHPA1:8 is observed with a statistically similar $\mathrm{LC}_{50}$ of $181.76 \mathrm{mg} \mathrm{L}^{-1}$.

To analyze the efficiency of larvicidal activity of natural products, some studies suggest some criteria, as there is still no standard concentration range for determining the efficiencies of natural products. It should be considered that these criteria are related to the time of exposure to the bioproducts and the origin of the larvae, which can change the LC $\mathrm{C}_{50} \mathrm{values}$ According to Komalamisra et al. (2005), $\mathrm{LC}_{50}$ between 100 and $750 \mathrm{mg} \mathrm{L}^{-1}$ are effective, up to 48 hours of exposure. Thus, the $\mathrm{LC}_{50}$ obtained for $P$. americana seed extracts obtained in this study can be correlated to effective alternatives in the control of Aedes aegypti.

The larvicidal action observed was also described in the study by Torres et al. (2014) in locations in the Philippines, in which the authors used two extracting solvents (ethanol and hexane), and $\mathrm{LC}_{50}$ was observed in P. americana seed extracts, respectively, at intervals from $16.48 \mathrm{mg} \mathrm{L}^{-1}$ to $20.61 \mathrm{mg} \mathrm{L}^{-1}$ and $9.82 \mathrm{mg} \mathrm{L}^{-1}$ to $13.39 \mathrm{mg} \mathrm{L}^{-1}$. Already in larvicidal trials performed by Agrela et al. (2014), in which methanol was adopted as solvent in P. americana seed extracts, the LC $\mathrm{C}_{50} \mathrm{Were}$ recorded for Rockerfeller and Mario Briceno Iragorry strains, respectively, $5.7 \mathrm{mg} \mathrm{L}^{-1}$ and $9.9 \mathrm{mg} \mathrm{L}^{-1}$. In a research carried out by Louis et al. (2020), in which the rind of the fruit of the same plant species was subjected to methanol extract, the $\mathrm{LC}_{50}$ detected for 3rd stage larvae was $7.12 \mathrm{mg} \mathrm{L}^{-1}$. 
Comparing with the $\mathrm{LC}_{50}$ results identified in the present study, it is noted that larvicidal activity was evidenced, however with a lower lethality potential, requiring a higher extract concentration to obtain the death of $50 \%$ of the larvae.

It is noteworthy that the results obtained with plant extracts may vary according to the period of collection, temperature, type of soil cultivated, plant species and others. For this reason, the isolation of the active compound from extracts is essential for standardization as a method of larval control (Gupta et al., 2011).

The solvent used can directly contribute to the variation of larvicidal activity, since it has been shown that the extraction of active biochemicals from plants requires the polarity of the solvents used (Ghost et al., 2012). The favorable results obtained encourage the continuation of the study, aiming at the isolation of the active principle and, mainly, ways that enable its practical use for the control of Aedes aegypti.

It was not yet possible through the study to specify which component or which components are responsible for larvicidal activity, because the isolation of such has not yet been verified. It is also necessary to perform the chemical characterization by chromatographic techniques of the extracts studied. Thus, it will be feasible to identify the metabolites to be attributed such larvicide potentials, being possible to generate bioproducts with bioprospecting activity for development of larvicide agents of plant origin.

\section{Conclusion}

The seeds of the species Persea americana presented a heterogeneity of secondary metabolites, encouraging future studies with other biological potentials. The tested extracts show activity against Aedes aegypti larvae, still revealing an atoxicity in the bioassay with Artemia salina against the non-target organism, showing selectivity against target organisms. Finally, the potential for using this product to control the vector responsible for the propagation of important arboviruses with high morbidity and mortality is confirmed and efficient, and should be explored in its control and combat.

\section{References}

Amado, D. A. V., Helmann, G. A. B., Detoni, A. M., Carvalho, S. L. C. D., Aguiar, C. M. D., Martin, C. A., \& Cottica, S. M. (2019). Antioxidant and antibacterial activity and preliminary toxicity analysis of four varieties of avocado (Persea americana Mill.). Brazilian Journal of Food Technology, 22.

Agrela, I. F., Hidalgo, Y., \& Herrera, F. (2014). Efecto larvicida de extractos metanólicos obtenidos de semillas y hojas de Persea americana (Laurales: Lauraceae)(aguacate) sobre Aedes aegypti (Diptera: Culicidae). Boletín de Malariología y Salud Ambiental, 54(2), $199-207$.

Chang, M. S., Christophel, E. M., Gopinath, D., \& Abdur, R. M. (2011). Challenges and future perspective for dengue vector control in the Western Pacific Region. Western Pacific surveillance and response journal: WPSAR, 2(2), 9.

Colegate, S. M., \& Molyneux, R. J. (Eds.). (2007). Bioactive natural products: detection, isolation, and structural determination. CRC press.

Deuschle, V. C., Brusco, I., Piana, M., Faccin, H., de Carvalho, L. M., Oliveira, S. M., \& Viana, C. (2019). Persea americana Mill. crude extract exhibits antinociceptive effect on UVB radiation-induced skin injury in mice. Inflammopharmacology, 27(2), 323-338.

Dolabela, M.F. (1997) Triagem in vitro para atividade antitumoral e anti Trypanossoma cruzi de extratos vegetais, produtos naturais e substâncias sintéticas. Dissertação (Mestrado), Instituto de Ciências Biológicas, Universidade Federal de Minas Gerais-UFMG, Belo Horizonte, 128 p.

Dabas, D., M Shegog, R., R Ziegler, G., \& D Lambert, J. (2013). Avocado (Persea americana) seed as a source of bioactive phytochemicals. Current pharmaceutical design, 19(34), 6133-6140.

Farmacopeia Brasileira. (5a ed.), ANVISA, 2010.

Ferrari, R. A. (2015). Nota Científica: Caracterização físico-química do óleo de abacate extraído por centrifugação e dos subprodutos do processamento. Braz. J. Food Technol., 18, 79-84.

Finney, D. J. (1952). Probit analysis: a statistical treatment of the sigmoid response curve. Cambridge university press, Cambridge.

Gobbo-Neto, L., \& Lopes, N. P. (2007). Plantas medicinais: fatores de influência no conteúdo de metabólitos secundários. Química nova, 30(2), 374-381.

Ghosh, A., Chowdhury, N., \& Chandra, G. (2012). Plant extracts as potential mosquito larvicides. The Indian journal of medical research, $135(5), 581$. 
Gupta, L., Deshpande, S., Tare, V., \& Sabharwal, S. (2011). Larvicidal activity of the $\alpha$-amylase inhibitor from the seeds of Macrotyloma uniflorum (Leguminosae) against Aedes aegypti (Diptera: Culicidae). International Journal of Tropical Insect Science, 31(1-2), 69-74.

Jorge, T. D. S. (2014). Avaliação reológica do óleo de abacate (Persea americana mill) e estudo da estabilidade sob condições de aquecimento e armazenamento à temperatura ambiente.

Kishore, R. K., Halim, A. S., Syazana, M. N., \& Sirajudeen, K. N. S. (2011). Tualang honey has higher phenolic content and greater radical scavenging activity compared with other honey sources. Nutrition research, 31(4), 322-325.

Komalamisra, N., Trongtokit, Y., Rongsriyam, Y., \& Apiwathnasorn, C. (2005). Screening for larvicidal activity in some Thai plants against four mosquito vector species. Southeast Asian Journal of Tropical Medicine and Public Health, 36(6), 1412.

Louis, M. L. M., Pushpa, V., Balakrishna, K., \& Ganesan, P. (2020). Mosquito larvicidal activity of Avocado (Persea americana Mill.) unripe fruit peel methanolic extract against Aedes aegypti, Culex quinquefasciatus and Anopheles stephensi. South African Journal of Botany, 133, 1-4.

Lugasi, A., Dworschák, E., Blazovics, A., \& Kery, A. (1998). Antioxidant and free radical scavenging properties of squeezed juice from black radish (Raphanus sativus L. var niger) root. Phytotherapy Research: An International Journal Devoted to Pharmacological and Toxicological Evaluation of Natural Product Derivatives, 12(7), 502-506.

Matos, F. D. A. (2005). Introdução à fitoquímica experimental. edições UFC.

McLaughlin, J. L. (1982). Brine shrimp: a convenient general bioassay for active constituents. Planta Med, 45, 31-32.

Moyses, V., \& Bonatti, A. F. (2021). A educação em saúde e a intersetorialidade como estratégia de prevenção e controle das arboviroses. The Brazilian Journal of Infectious Diseases, 25, 101175.

Nerio, L. S., Olivero-Verbel, J., \& Stashenko, E. (2010). Repellent activity of essential oils: a review. Bioresource technology, 101(1), 372-378.

Oliveira, A. C. D., Valentim, I. B., Goulart, M. O. F., Silva, C. A., Bechara, E. J. H., \& Trevisan, M. T. S. (2009). Fontes vegetais naturais de antioxidantes. Química Nova, 32, 689-702.

Pavela, R. (2015). Essential oils for the development of eco-friendly mosquito larvicides: A review. Ind Crops and Prod,76, 174-187

Rotta, E. M., de Morais, D. R., Biondo, P. B. F., dos Santos, V. J., Matsushita, M., \& Visentainer, J. V. (2016). Use of avocado peel (Persea americana) in tea formulation: a functional product containing phenolic compounds with antioxidant activity. Acta Scientiarum. Technology, 38(1), $23-29$.

Reed, L.J. e Muench, H. (1938) Um método simples de estimar 5\% de endpoints. American Journal of Hygiene, 27, $493-497$.

Shaalan, E. A. S., Canyon, D. V., Bowden, B., Younes, M. W. F., Abdel-Wahab, H., \& Mansour, A. H. (2006). Efficacy of botanical extracts from Callitris glaucophylla against Aedes aegypti and Culex annulirostris mosquitoes. Tropical Biomedicine, 23, 180-185.

Simões, C. M. O., Schenkel, E. P., de Mello, J. C. P., Mentz, L. A., \& Petrovick, P. R. (2017). Farmacognosia: do produto natural ao medicamento. Artmed Editora.

Silva, H. H. G., Silva, I. G. D., Elias, C. N., Lemos, S. P. S., \& Rocha, A. P. (1995). Idade fisiológica dos ovos de aedes (stegomyia) aegypti (Linnaeus, 1762) (diptera, culicidae). Revista Pat. Trop. 24(2), 269-273.

Thomas, S. J., \& Yoon, I. K. (2019). A review of Dengvaxia®: Development to deployment. Human vaccines \& immunotherapeutics, 15 (10), $2295-2314$.

Torres, R. C., Garbo, A. G., \& Walde, R. Z. M. L. (2014). Larvicidal activity of Persea americana Mill. against Aedes aegypti. Asian Pacific journal of tropical medicine, 7, S167-S170.

Valente, G. C. (2020). Caracterização e análise comparativa dos óleos extraídos da semente e da polpa do abacate (Persea americana Mill.) utilizando diferentes métodos de extração.

Viana, L. R. D. C., Pimenta, C. J. L., Araújo, E. M. N. F. D., Teófilo, T. J. S., Costa, T. F. D., \& Costa, K. N. D. F. M. (2018). Reemerging arboviruses: clinical-epidemiological profile of hospitalized elderly patients. Revista da Escola de Enfermagem da USP, 52.

Yasir, M., Das, S., \& Kharya, M. D. (2010). The phytochemical and pharmacological profile of Persea americana Mill. Pharmacognosy reviews, 4(7), 77. 